\title{
Effect of Sophorolipid Biosurfactant on Oil Biodegradation by the Natural Oil-Degrading Bacteria on the Weathered Biodiesel, Diesel and Light Crude Oil
}

Nayereh Saborimanesh and Catherine N. Mulligan*

Department Building, Civil and Environmental Engineering,1455 de Maisonneuve Blvd. West, Montreal, Quebec, H3G 1M8, Canada

\begin{abstract}
This study investigated the role of natural oil-degrading bacteria in the weathered biodiesel (BD), diesel (D) and light crude oil $(\mathrm{L})$ in oil biodegradation in seawater with and without sophorolipid biosurfactant. Mixtures of artificial seawater and weathered oil with and without sophorolipid dispersant were incubated at $22 \pm 1^{\circ} \mathrm{C}$ and $100 \mathrm{rpm}$ for 28 days. Analysis of the remaining of total petroleum hydrocarbons showed degradation of $43 \pm 0.7 \%, 45 \pm 5.7 \%$ and $39 \pm 4.6 \%$ of biodiesel, diesel and light crude oil, respectively, during the natural biodegradation and $44 \pm 5 \%, 47.5 \pm$ $3.9 \%$ and $44 \pm 1 \%$ of biodiesel, diesel and light crude oil, respectively, with sophorolipid by the existing bacteria after 28 days. Characterization of bacteria isolated from the BD, $D$ and $L$ oil by $16 S$ rRNA pyrosequencing showed that the Firmicutes was the dominant phylum in biodiesel $(100 \%)$ and diesel $(53 \%)$. The Actinobacteria was dominant in the diesel $(47 \%)$ and the Proteobacteria $(97 \%)$ and Actinobacteria (3\%) were the two dominant phyla in the light crude oil. The hydrophobicity results showed that the bacteria consumed the hydrocarbons mainly by changing their cell surface structures in the natural biodegradation treatment and increase in the micellar dispersion of hydrocarbons in the biodegradation treatment with the sophorolipid. This study confirmed the significant contribution of natural bacteria in the weathered diesel, biodiesel and light crude oil in the biodegradation and the positive effect of sophorolipid on the biodegradation.
\end{abstract}

\section{Introduction}

Oil spills are usually referred to as the petroleum based hydrocarbons that enter to the aquatic environments [1-3]. Spilled-oil can last for a long time before it can be cleaned up by the natural removal processes (e.g., evaporation, dispersion and biodegradation) [4]. Success in the biological treatment of hydrocarbons strongly depends on the presence of active oil-degrading microorganisms in the contaminated site, the bioavailability of hydrocarbons and the environmental conditions [5-8]. According to Okafor [6] nearly $0.1-1 \%$ and $1-10 \%$ of the indigenous "heterotrophic bacterial communities" in the unpolluted and oil-polluted marine environments, respectively, are capable of uptaking the petroleum hydrocarbons (HCs) [6]. It was found that, the microorganisms can consume the HCs through different ways that can occur simultaneously or at different stages of HCs uptake $[3,9]$. For example, microorganisms may first uptake the HCs that are soluble in seawater and then interact with the hydrophobic hydrocarbons if they can change their cell surface structures to hydrophobic or hydrophilic states, based on the available HCs [3,9]. Moreover, if they can naturally produce surfactant-like products (known as "biosurfactants", that are composed of two parts, a hydrophilic part and a hydrophobic part), they can also uptake the oil droplets or hydrocarbons that encapsulated within the micelles (structures that form when the biosurfactant molecules interact with water and HCs) [3,9]. Since the main constituents of spilled oil are not readily water-soluble, the uptake of hydrocarbons by the microorganisms is either very limited $[5,9,10]$ or restricted to microorganisms that are capable of the biosurfactant production. For example, Pseudomonas species produce particular biosurfactants to uptake the hydrocarbons at different biodegradation periods $[11,13]$. Due to the chemical (e.g., hydrophobic nature of hydrocarbons), microbial (e.g., inability of all oil-degrading microorganisms in biosurfactant production) and environmental limitations (e.g., low temperature), the biological or chemical agents (e.g., chemical dispersants, nutrients) were added to the oil-impacted environments $[5,14]$ to accelerate the dispersion and consequently the bioavailability of HCs.
The addition of chemical dispersants to the oil-impacted sites has been extensively practiced over the last few decades $[15,16]$. This is because the chemical dispersants are composed of both hydrophilic (water-like) and hydrophobic (water-repellant) parts in their structures [16]. Therefore, they are able to simultaneously interact with oil and water molecules and disperse the spilled oil in the water. When dispersants contact the dispersed oil, they influence (usually decrease) the oil-water interfacial tension. This leads to the formation of oil droplets if mixing is provided [17]. Then the formed droplets are dispersed through encapsulation in the micelles [18].

To date, the ultimate goal of application of various additives including chemical dispersants was to increase the bioavailability of spilled oil to the indigenous oil-degrading microorganisms in the oilcontaminated environments [1,16,19-21], and the role of oil-degrading microorganisms present in the spilled oil was not understood. The study that investigated the role of natural bacteria on hydrocarbon (e.g., crude oil) biodegradation in seawater showed that nearly $66 \%$ of oil was degraded during 56 days of biodegradation by the active bacteria in the spilled-oil [22]. However, the effect of additives (e.g, biosurfactant)

${ }^{*}$ Corresponding author: Catherine N. Mulligan, Department Building, Civil and Environmental Engineering, Concordia University - 1455 de Maisonneuve Blvd West, Montreal, Quebec, Canada H3G 1M8, Tel: +1-514-848-2424; E-mail: mulligan@civil.concordia.ca

Received September 03, 2015; Accepted October 08, 2015; Published October 10, 2015

Citation: Saborimanesh N, Mulligan CN (2015) Effect of Sophorolipid Biosurfactant on Oil Biodegradation by the Natural Oil-Degrading Bacteria on the Weathered Biodiesel, Diesel and Light Crude Oil. J Bioremed Biodeg 6: 314. doi:10.4172/2155-6199.1000314

Copyright: () 2015 Saborimanesh N, et al. This is an open-access article distributed under the terms of the Creative Commons Attribution License, which permits unrestricted use, distribution, and reproduction in any medium, provided the original author and source are credited. 
Citation: Saborimanesh N, Mulligan CN (2015) Effect of Sophorolipid Biosurfactant on Oil Biodegradation by the Natural Oil-Degrading Bacteria on the Weathered Biodiesel, Diesel and Light Crude Oil. J Bioremed Biodeg 6: 314. doi:10.4172/2155-6199.1000314

on natural bacteria on spilled oil has not been considered.

The main objectives of this study were to determine the identity of bacteria naturally present in the weathered biodiesel, diesel and light crude oil in the oil biodegradation and to determine the effect of sophorolipid biosurfactant on the biodegradation of diesel, biodiesel and light crude oil by those bacteria.

This study provides information regarding the role of indigenous oil-degrading bacteria in the spilled oil biodegradation in the marine environment and the effect of sophorolipid biosurfactant on their activities.

\section{Materials and Methods}

\section{Chemicals}

The sophorolipid biosurfactant was supplied by Ecover Company (Belgium N.V, SL18, 41\%). Diesel and light crude oil were purchased from Petro-Canada and biodiesel was supplied by Rothsay Biodiesel Company in Montreal, Canada. Deionized water was used for dilution of the original sophorolipid solution and seawater preparation. The fresh biodiesel, diesel and light crude oil were artificially weathered (following the Wang et al. [23] method with modifications) under a fume hood for $72 \mathrm{~h}$ to simulate the weathering conditions and reduce the effects of volatile hydrocarbons on the biodegradation experiment. The synthetic seawater was a brine solution $(30 \mathrm{~g} \mathrm{NaCl} / \mathrm{L})$ amended with necessary elements for the microbial growth and was prepared following the swirling flask dispersant effectiveness test with slight modifications [24]. The synthetic seawater consisted of $\mathrm{NaCl}$ salt $(30 \mathrm{~g} / \mathrm{L})$, nitrogen and phosphate $(\mathrm{N} \& \mathrm{P})$ solution, and main and trace element solutions. The N\&P stock solution consisted of $\mathrm{Na}_{2} \mathrm{HPO}_{4} \cdot 2 \mathrm{H}_{2} \mathrm{O}(18.40 \mathrm{~g} / \mathrm{L})$ and $\mathrm{KNO}_{3}(76.30 \mathrm{~g} / \mathrm{L})$. The trace element stock solution consisted of $\mathrm{MnSO}_{4} \cdot \mathrm{H}_{2} \mathrm{O}(30.2 \mathrm{mg} / \mathrm{L}), \mathrm{H}_{3} \mathrm{BO}_{3}(57.2$ $\mathrm{mg} / \mathrm{L}), \mathrm{ZnSO}_{4} .7 \mathrm{H}_{2} \mathrm{O}(42.8 \mathrm{mg} / \mathrm{L})$ and $\left(\mathrm{NH}_{4}\right)_{6} \mathrm{Mo}_{7}\left(\mathrm{O}_{2}\right)_{4}(34.7 \mathrm{mg} / \mathrm{L})$. The three main element solutions consisted of $\mathrm{MgSO}_{4} .7 \mathrm{H}_{2} \mathrm{O}(22.5 \mathrm{~g} / \mathrm{L})$, $\mathrm{CaCl}_{2} .2 \mathrm{H}_{2} \mathrm{O}(27.50 \mathrm{~g} / \mathrm{L})$, and $\mathrm{FeCl}_{2} \cdot 6 \mathrm{H}_{2} \mathrm{O}(0.25 \mathrm{~g} / \mathrm{L})$. All five stock solutions were separately autoclaved $\left(121^{\circ} \mathrm{C}, 20 \mathrm{~min}\right)$ and kept at room temperature $\left(22 \pm 1^{\circ} \mathrm{C}\right)$. Fresh solutions were prepared as the sign of chemical and biological degradation were observed. Prior to each test, the $\mathrm{N} \& \mathrm{P}$ solution $(10 \mathrm{~mL})$, the trace elements $(2 \mathrm{~mL})$ and the main element solutions $(2 \mathrm{~mL}$ of each) and the $\mathrm{NaCl}$ salt $(30 \mathrm{~g})$ were added to the deionized water $(1 \mathrm{~L})$ [24]. The $\mathrm{pH}$ and temperature was recorded and dilute $\mathrm{HCl}(1 \%)$ or $\mathrm{NaOH}(0.1 \mathrm{~N})$ were used to adjust the $\mathrm{pH}$.

Two sets of hydrocarbons (biodiesel, diesel and light crude oil) were prepared for this study. The first set of hydrocarbons was weathered but not sterilized and specifically used as the source of microbial culture and also the source of hydrocarbon in the biodegradation experiment. The second set of hydrocarbons (already weathered) was used only for the microbiological analysis tests (after the biodegradation experiment). This set was initially sterilized $(0.22 \mu \mathrm{m}$ pore size, d: 25 $\mathrm{mm}$, Fisher Scientific, EMD Millipore MF-Millipore ${ }^{\mathrm{nm}}$ Mixed Cellulose Ester Membranes) to remove all present microbial communities in the oils. This oil was only used as the source of hydrocarbons for the microorganisms. The oil was kept in amber vials at room temperature.

\section{Biodegradation experiments}

Biodegradation experiments were carried out according to the modified method adapted from the USEPA-bioremediation agent effectiveness [24] and the method proposed by McKew et al. [1]. The indigenous microbial communities were used without any enrichment. Three treatments including the control (no bacteria), natural (with bacteria) and natural treatment with external sophorolipid addition were designed to investigate the oil biodegradation by the active bacteria present in the tested oils.

The control treatment contained the artificial seawater (20 $\mathrm{mL})$ and sterilized weathered oil $(100 \mu \mathrm{L})$. The natural treatment contained the artificial seawater $(20 \mathrm{~mL})$ and weathered but not sterilized hydrocarbons $(100 \mu \mathrm{L})$. The natural treatment with external sophorolipid contained the synthetic seawater $(20 \mathrm{~mL})$, weathered but not sterilized hydrocarbons $(100 \mu \mathrm{L})$ and sophorolipid solution $(100$ $\mu \mathrm{L}, 80 \mathrm{mg} / \mathrm{L})$. Biodegradation vials incubated on an orbital shaker (Thermolyne AROS) at $100 \pm 1 \mathrm{rpm}$ and room temperature $\left(22 \pm 1^{\circ} \mathrm{C}\right)$ for 28 days. Samples covering days 0, 7, 5, 21 and 28 (for each oil) were taken to analyze the total petroleum hydrocarbon (TPHs), the bacterial enumeration and the bacterial characterization.

Bacterial Verification: The Bushnell-Hass (B-H) media was used to recover the active indigenous oil-degrading bacteria in the tested oils. The Bushnell-Hass is a specific media that only recovers the oil-degrading bacteria [25]. The B-H media was supplemented with the weathered sterilized diesel, biodiesel and light crude oil as the source of hydrocarbons. The $\mathrm{B}-\mathrm{H}$ media was prepared by the addition of magnesium sulfate $(0.2 \mathrm{~g} / \mathrm{L})$, calcium chloride $(0.02 \mathrm{~g} / \mathrm{L})$, monopotassium phosphate, dipotassium phosphate and ammonium nitrate $(1 \mathrm{~g} / \mathrm{L}$ each), ferric chloride $(0.05 \mathrm{~g} / \mathrm{L})$ and $10-15 \mathrm{~g}$ of solidifier to deionized water (final pH $7.0 \pm 0.2$ at $22^{\circ} \mathrm{C}$, autoclaved at $121^{\circ} \mathrm{C}, 20$ $\mathrm{min}$ ). The plating was done in two steps including serial dilution and aseptic spreading. The serial dilution of the biodegradation samples was done by diluting the aqueous phase of the biodegradation samples $(0.5$ $\mathrm{mL}$ ) of each sampling day with $4.5 \mathrm{~mL}$ of phosphate buffer solution (1M, pH 7.4 at $25^{\circ} \mathrm{C}$, to obtain dilutions of $\geq 10^{-5}$, Sigma-Aldrich). The aseptic spreading of the dilutions $(100 \mu \mathrm{L})$ was conducted by the spreading of the diluted samples and the sterilized weathered diesel $(20 \mu \mathrm{L})$, biodiesel $(20 \mu \mathrm{L})$ and light crude oil $(20 \mu \mathrm{L})$ on the duplicate Bushnell-Hass plates. The plates were sealed with Parafilm and incubated at room temperature $\left(22 \pm 1^{\circ} \mathrm{C}\right)$ until the bacterial colonies were observed. The number of observed colonies was reported as the colony-forming units (CFU) per $\mathrm{mL}$ of samples.

Chemical analysis of TPHs: The level of biodegradation at various periods was monitored weekly by analysis of the remaining of total petroleum hydrocarbons (TPHs) at days $0,7,14,21$ and 28. When the vials were taken from the shaker, the samples were solvent extracted according to the swirling flask dispersant effectiveness test [24]. First, the samples were centrifuged $(10000 \mathrm{rpm}, 10 \mathrm{~min})$ to separate the biomass from the aqueous phase. The aqueous phase was extracted (3X) with $5 \mathrm{~mL}$ of $\mathrm{n}$-hexane (95\%, Sigma-Aldrich Canada Co.) and the extracted hydrocarbons $(15 \mathrm{~mL})$ were further diluted by the addition of hexane $(5 \mathrm{~mL})$. The analysis of the extracted mixture was conducted by a CP-3800 VARIAN gas chromatograph (GC-FID) in the splitless mode and with the oven and detector temperatures of $250^{\circ} \mathrm{C}$ and a total run time of $33 \mathrm{~min}\left(2 \mathrm{~min}\right.$ hold at $40^{\circ} \mathrm{C}$ and $6 \mathrm{~min}$ hold at $\left.250^{\circ} \mathrm{C}\right)$ The percentage of biodegraded oil was calculated as ((Cin-C residual)/ Cin) $\times 100 \%$, where Cin is the initial concentration of oil added to the biodegradation samples and the Cresidual is the concentration of oil remaining at different biodegradation periods.

Bacterial communities characterization: Characterization of the natural microbial communities was conducted by pyrosequencing of $16 \mathrm{~S}$ rRNA. Three samples of day- 0 of the biodegradation experiment were selected to identify the original bacterial communities in the tested oils. Samples $(20 \mathrm{~mL})$ were centrifuged $(10000 \mathrm{rpm}, 10 \mathrm{~min})$ and the biomass was washed (2X) with $\mathrm{n}$-hexane (95\%, Sigma-Aldrich). 
Citation: Saborimanesh N, Mulligan CN (2015) Effect of Sophorolipid Biosurfactant on Oil Biodegradation by the Natural Oil-Degrading Bacteria on the Weathered Biodiesel, Diesel and Light Crude Oil. J Bioremed Biodeg 6: 314. doi:10.4172/2155-6199.1000314

This step was conducted to remove the oil residue from the biomass. The phenol-chloroform method [1] was followed for the genomic DNA extraction. Briefly, the biomass was initially transferred to tubes $(2 \mathrm{~mL})$ that contained $0.5 \mathrm{~g}$ of glass beads and a $1 \mathrm{~mL}$ of phenol-chloroformisoamyl alcohol (25:24:1, Sigma-Aldrich). The mixture was vortexed (5 $\mathrm{sec})$, bead beated (20 sec, Mini Vortex, Fisher Scientific) and centrifuged $(12000 \times \mathrm{g}, 5 \mathrm{~min}$, Thermo Scientific). This step was repeated until no layer was observed between two phases. The upper layer was transferred to the clean tubes $(2 \mathrm{~mL})$ and the chloroform-isoamyl alcohol $(450 \mu \mathrm{L}$, 24:1, Biotechnology grade, Amresco) was added to the tubes, vortexed $(10 \mathrm{sec})$ and centrifuged $(12000 \times \mathrm{g}, 5 \mathrm{~min})$. The aqueous phase of this step was transferred to a clean $(2 \mathrm{~mL})$ collection tube and $70 \mu \mathrm{L}$ of sodium acetate $(3 \mathrm{M})$ and ice-cold isopropanol $(1 \mathrm{~mL})$ were added to the tubes. The mixture was gently shaken and incubated at $-20^{\circ} \mathrm{C}$ overnight. Following the incubation time, the mixture was centrifuged (12000×g, $5 \mathrm{~min})$ and the upper phase was discarded. A $70 \%$ ethanol $(1 \mathrm{~mL})$ was used to wash $(2 \mathrm{X})$ the precipitated DNA by centrifuging the mixture at $12000 \times \mathrm{g}$ for $5 \mathrm{~min}$. The DNA was finally air dried and mixed with $50 \mu \mathrm{L}$ of ultra-pure distilled water (Invitrogen) and stored at $-20^{\circ} \mathrm{C}[1]$

The purity of the genomic DNA was examined by running the genomic DNA on a $1.5 \%$ agarose gel electrophoresis using triethanolamine buffer solution (TEA) (a mixture of Tris base, acetic acid and ethylenediaminetetraacetic acid (EDTA)). The concentration of genomic DNA was quantified using the PicoGreen DNA assay kit (Quant-iT) by spectrophotometer. This step was followed by the amplification of the quantified genomic DNA using the polymerase chain reaction, $16 \mathrm{~S}$ rRNA. The $16 \mathrm{~S}$ rRNA contains three forward primers and one reverse primer. The sequences of forward primers are 5'-CCTACGGGRGGCAGCAG-3', 5' -ACWYCTACGGRWGGCTGC$3^{\prime}$ and $5^{\prime}$-CACCTACGGGTGGCAGC- $3^{\prime}$ and the reverse primer sequences are $5^{\prime}$-TACNVGGGTHTCTAATCC-3'. The PCR master mixture (Bioline Co.) for each reaction contained the following components: forward and reverse primers $(2.5 \mu \mathrm{L}$ each), $2.5 \mu$ mole $\mathrm{MgCl}_{2}(2.5 \mu \mathrm{L})$, Taq polymerase enzyme $(0.5 \mu \mathrm{L}), 5 \mathrm{X}$ reaction buffer $(10 \mu \mathrm{L})$, dNTP-deoxynucleoside triphosphate $(0.5 \mu \mathrm{L})$, genomic DNA template $(2 \mu \mathrm{L})$, ultra-pure distilled water $(29.5 \mu \mathrm{L}$, Invitrogen). The genomic DNA from E.coli and deionized water were used as the positive and negative controls. The hot start PCR cycling conditions were as follows. One cycle of hot start at $94^{\circ} \mathrm{C}$ for $5 \mathrm{~min}$ was followed by 30 cycles at the same temperature each for $1 \mathrm{~min}, 30$ cycles at $55^{\circ} \mathrm{C}$ for $30 \mathrm{sec}, 30 \mathrm{cycles}$ at $72^{\circ} \mathrm{C}$ for $1.5 \mathrm{~min}$ and finally one cycle of extended elongation at $72^{\circ} \mathrm{C}$ for $8.5 \mathrm{~min}$. The PCR products were then cleaned with the UltraClean PCR Clean-Up Kit (MO BIO Co.). The final concentration of the products was determined by Bioanalyzer 1000 (Agilent Technologies) and samples were submitted to the McGill Genome Center.

The obtained sequences were submitted to the Ribosomal Database Project (RDP, available at http://rdp.cme.msu.edu/seqmatch/ seqmatch_intro.jsp) with the Pyrosequencing Pipeline Initial Process described by Cole et al. [26]. The trimming process (e.g., mismatch adapters, barcodes and primers) was conducted by the default parameters and the sequences $\leq 150$ were not included in the analyzes [27]. The average length of the analyzed sequences was around $450 \mathrm{bps}$. The RDP classifier was used to conduct the taxonomic classification and the bacterial sequences of each sample (e.g., biodiesel, diesel and light crude oil samples) carried out individually. The similarities of $\geq$ $97 \%$ were reported as dominant bacteria in each sample.

Determination of oil uptake by bacterial communities: The modified microbial adhesion to the hydrocarbon protocol [28, 29]was followed to determine the hydrocarbon uptake by the indigenous bacterial communities in the weathered oils. Before the test, the biodegradation samples $(20 \mathrm{~mL}$, day-7 of the biodegradation) were enriched by transferring the entire samples to the fresh Luria Broth (SigmaAldrich) and incubating for $18-24 \mathrm{~h}$ at $100 \mathrm{rpm}$ and room temperature (Orbital shaker, Thermolyne AROS). The enriched samples were then centrifuged $(10000 \mathrm{rpm}, 10 \mathrm{~min})$ and the biomass was washed $(2 \mathrm{X})$ with a buffer solution $\left(\left(\mathrm{pH} 7.4, \mathrm{MnSO}_{4} .7 \mathrm{H}_{2} \mathrm{O}(0.2 \mathrm{~g} / \mathrm{L})\right.\right.$, urea $\left(\mathrm{CH}_{4} \mathrm{~N}_{2} \mathrm{O}\right.$; $1.8 \mathrm{~g} / \mathrm{L}), \mathrm{KH}_{2} \mathrm{PO}_{4}(7.26 \mathrm{~g} / \mathrm{L})$ and $\left.\mathrm{K}_{2} \mathrm{HPO}_{4} .7 \mathrm{H}_{2} \mathrm{O}(22.2 \mathrm{~g} / \mathrm{L})\right)$ and then with sterilized synthetic seawater (salinity of $30 \mathrm{ppt}, \mathrm{pH}$ 7.2) to remove the impurities. Bacterial cells were diluted in the artificial seawater (30 ppt, pH 7.2) until an absorbance of $1.0 \mathrm{~A}(\mathrm{~A} 0)$ at $600 \mathrm{~nm}$ was obtained by a UV-visible spectrophotometer (Lambda 20). The mixture was dispensed in separatory funnels $(\sim 25 \mathrm{~mL}$ in each) followed by the addition of (i) a $1 \mathrm{~mL}$ of weathered sterilized hydrocarbons (biodiesel and diesel were syringe filtered $(0.2 \mu \mathrm{m})$, and light crude oil was autoclaved at $121^{\circ} \mathrm{C}$ for $20 \mathrm{~min}$ and cooled to room temperature), (ii) mixture of weathered sterilized hydrocarbons and sophorolipid solution. The mixtures were thoroughly mixed $(3000 \mathrm{rpm}, 2 \mathrm{~min})$ and the optical density (OD: $600 \mathrm{~nm}$ ) of biomass-aqueous phase $(1.5 \mathrm{~mL})$ of each treatment was measured after $1 \mathrm{~h}$.

The bacterial cell surface hydrophobicity (CSH) was calculated from the decrease in the turbidity of biomass in the aqueous phase (which shows the adherence of biomass to hydrocarbons or sophorolipid) following each treatment (A1) to the initial absorbance of suspended biomass $(\mathrm{A} 0),[1-(\mathrm{A} 1 / \mathrm{A} 0) \times 100]$. A positive $\mathrm{CSH}$ was reported as the hydrophobicity (tendency to interact with the hydrophobic compounds) and the negative CSH was reported as the hydrophilicity (tendency to interact with the hydrophilic compounds).

\section{Results and Discussion}

\section{Role of indigenous oil-degrading bacteria in the weathered diesel, biodiesel and light crude oil biodegradation}

Few studies have focused on the role of indigenous bacteria in the spilled oil biodegradation. In this study, the bacteria with a high capability of consuming the weathered biodiesel, diesel and light crude oil as the hydrocarbon source was confirmed through (1) chemical analysis of hydrocarbon (TPHs) concentrations at different days of the biodegradation experiment (2) visual observation of the microbial colonies on the Bushnell-Hass plates and (3) microbial verification by the pyrosequencing technique.

Figures 1 and 2 show the biodegradation of weathered diesel, biodiesel and light crude oil (total petroleum hydrocarbons) and bacterial growth in the natural and sophorolipid treatments. The chemical analysis of total hydrocarbons in the control treatment (artificial seawater only) at different sampling days showed no oil biodegradation, while high levels of biodegradation were observed in the natural treatment at different sampling days. For example, the initial concentration $(5000 \mathrm{mg} / \mathrm{L})$ of weathered biodiesel, diesel, and light crude oil by bacteria was reduced to less than $3000 \mathrm{mg} / \mathrm{L}$ during the 28 days of the biodegradation process. The highest level of biodegradation of diesel $(27 \pm 2.2 \%)$, biodiesel $(28 \pm 4 \%)$, and light crude oil (30 \pm $1 \%$ ), during the natural treatment and $28 \pm 2.64 \%$ (diesel), $28 \pm 3.3 \%$ (biodiesel), and $30 \pm 1 \%$ (light crude oil) during the biosurfactant treatment occurred during the first 7 days of biodegradation period. The biodegradation continued in the following days in both natural and sophorolipid treatments and slowed down from day 14 to day 28, at which the maximum biodegradation reached $43 \pm 1 \%$ (biodiesel), 
Citation: Saborimanesh N, Mulligan CN (2015) Effect of Sophorolipid Biosurfactant on Oil Biodegradation by the Natural Oil-Degrading Bacteria on the Weathered Biodiesel, Diesel and Light Crude Oil. J Bioremed Biodeg 6: 314. doi:10.4172/2155-6199.1000314

$45 \pm 6 \%$ (diesel) and $39 \pm 5 \%$ (light crude oil) in the natural treatment and $45 \pm 5 \%$ (biodiesel), $48 \pm 4 \%$ (diesel) and $44 \pm 1 \%$ (light crude oil) in the sophorolipid treatment, respectively. In addition, no microbial population was observed on the plates with the sterilized biodiesel, diesel and light crude oil (control), while nearly 100, 370, 760 $\mathrm{CFU} / \mathrm{mL}$ were grown on the Bushnell-Hass plates cultured with the aqueous phase of the day 0 of biodegradation samples (contained the unsterilized weathered biodiesel, diesel and light crude oil).

The presence of oil-degrading bacteria in oil-contaminated marine environments was previously reported in the literature [30,31]. Previous studies showed the presence and role of the oil-degrading bacteria in the contaminated environments, where the oil spill occurred, instead of in the spilled oil. This study showed that the oil-degrading bacteria are also present in the spilled oil. The results of this study are in agreement with a previous study [22] that investigated the capability of the oil-

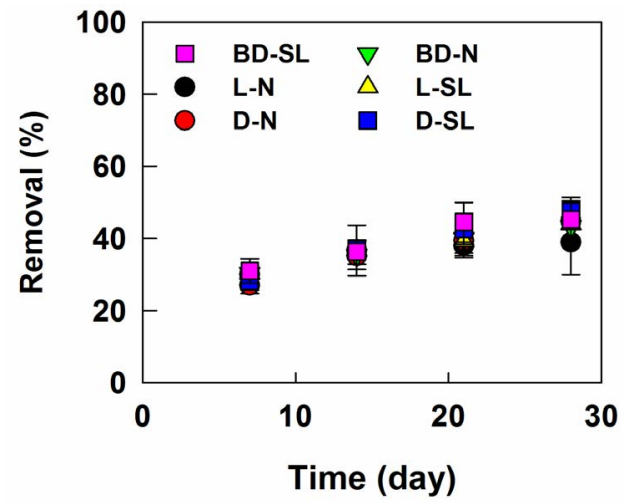

Figure 1: Biodegradation of weathered diesel (D), biodiesel (BD) and light crude $(\mathrm{L})$ oil with and without sophorolipid (SL) biosurfactant during 28 days of incubation at $100 \mathrm{rpm}$ and $22 \pm 1^{\circ} \mathrm{C}$.

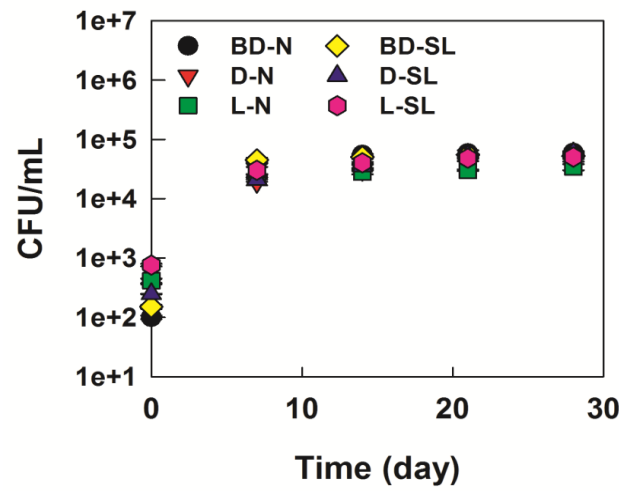

Figure 2: Bacterial populations recovered from the weathered biodiesel (BD) diesel (D) and light crude (L) oil with and without sophorolipid (SL) grown on the Bushnell-Hass plates. degrading microorganisms present on the weathered crude oil on biodegradation of oil in seawater. Although different culture media (minimal salt media) were used for the microbial growth in their study, a significantly higher bacterial population was recovered from the plates cultured with the weathered crude oil (e.g., $41200 \pm 511$ CFU/ $\mathrm{mL}$ ) than the plates cultured with the bacterial communities isolated from the seawater (Gulf St. Vincent, SA, Australia) where the levels of $66 \pm 3 \mathrm{CFU} / \mathrm{mL}$ were determined [22].

The pyrosequencing technique was used to identify the dominant bacteria in the diesel, biodiesel, and light crude oil. Analysis of pyrosequencing results revealed four major phyla including Firmicutes, Actinobacteria, Actinobacteria and Proteobacteria in the tested oils. The Firmicutes was the dominant phylum in biodiesel (100\%) and diesel (53\%). The Actinobacteria was also dominant in the diesel (47\%) oil and the Proteobacteria (97\%) and Actinobacteria (3\%) were the dominant phyla in the light crude oil. The majority of the isolated bacteria were identified as orders of Bacillales, Actinomycetales and Sphingomonadales. For example, Bacillales was the dominant order isolated from the biodiesel oil. Two dominant orders including Acinetobacter and Bacillales were isolated from the diesel and Sphingomonadales was the dominant order in the light crude oil. Table 1 summarizes the characteristics of bacteria recovered from the biodiesel, diesel and light crude oil by the pyrosequencing technique.

Assessment of the characteristics of the dominant bacteria isolated from the biodiesel, diesel and light crude oil revealed that they either have a high potential for biosurfactant production or are a known oildegrading bacteria [32-34]. For example, the biosurfactant production of Firmicutes phylum was reported in several studies [35-38]. Similarly, the Paenibacillus genus and its members were found to effectively degrade diesel through biosurfactant production [34,39].

\section{Oil uptake by bacteria}

The microbial adhesion to hydrocarbon test was used to verify the mechanisms of oil uptake by the natural bacteria in the weathered oils. Figure 3 shows the variation in the cell surface hydrophobicity of isolated bacteria under the natural (control) and sophorolipid treatments. In the natural (control) treatment the bacteria were incubated on the diesel, biodiesel and light crude oil. In the sophorolipid treatments, the bacteria were incubated on (i) only the sophorolipid biosurfactant and (ii) the combinations of sophorolipid and diesel, biodiesel and light crude oil.

The results of the cell surface hydrophobicity (CSH) in the control showed that the isolated bacteria recovered from the biodiesel had hydrophilic properties (negative $\mathrm{CSH}$, tendency to interact with the hydrophilic compounds), while the isolated bacteria recovered from the diesel and light crude oils had hydrophobic properties (positive $\mathrm{CSH}$, tendency to interact with the hydrophobic compounds). For example, the hydrophobicity values of $-50 \%, 16 \%$ and $2 \%$ were obtained

\begin{tabular}{|c|c|c|c|c|c|}
\hline \multirow{2}{*}{$\begin{array}{c}\text { Classifications } \\
\text { Phylum }\end{array}$} & \multirow{2}{*}{$\begin{array}{l}\text { Biodiesel } \\
\text { Firmicutes }\end{array}$} & \multicolumn{2}{|c|}{ Diesel } & \multicolumn{2}{|c|}{ Light crude oil } \\
\hline & & Actinobacteria & Firmicutes & Proteobacteria & Actinobacteria \\
\hline Class & Bacilli & Actinobacteria & Bacilli & Alphaproteobacteria & Actinobacteria \\
\hline Order & Bacillales & Actinomycetales & Bacillales & Sphingomonadales & Actinomycetales \\
\hline Family & Bacillaceae & Dietziaceae & Paenibacillaceae & Sphingomonadaceae & Mycobacteriaceae \\
\hline Genus & Bacillus & Dietzia & Paenibacillus & Sphingomonas & Mycobacterium \\
\hline Dominancy (\%) & 100 & 47 & 53 & 97 & 3 \\
\hline
\end{tabular}

Table 1: Classification of natural bacterial communities present in biodiesel, diesel and light crude oil by pyrosequencing. 


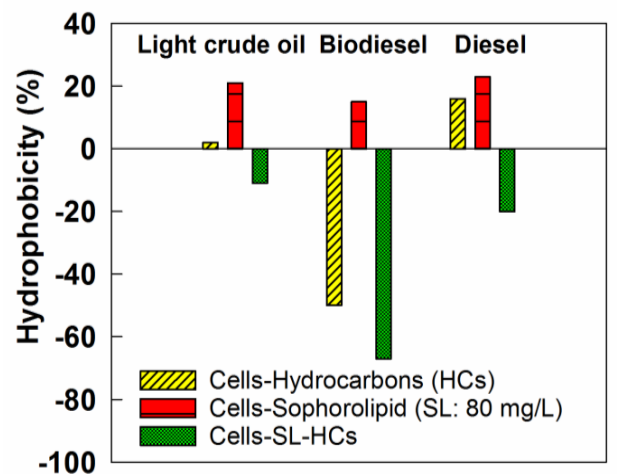

Figure 3: Bacterial cell modification following the exposure of bacterial communities in the weathered biodiesel, diesel and light crude oil to the diesel, biodiesel and light crude oil, the sophorolipid biosurfactant individually and in combination. The SD values are $\geq 0.5 \%$

following $1 \mathrm{~h}$ of incubation of bacterial cells on the biodiesel, diesel and light crude oil, respectively.

The examination of biodiesel-isolated bacteria (e.g., Bacillus) incubated on the weathered biodiesel and diesel showed that the bacteria changed the cell surface hydrophobicity (CSH) from $-50 \%$ to $-60 \%$, as they were exposed to biodiesel and modified their $\mathrm{CSH}$ from $-50 \%$ to nearly $+1 \%$ when exposed to weathered diesel. This test clearly showed the capability of the bacteria in cell modification as exposed to the different types of hydrocarbons. The results of this study are in agreement with the studies on the effect of hydrocarbons on the bacterial cell surface properties $[3,40,41]$. For example, Bouchez Naitali et al. [3] showed that cell surface hydrophobicities of $69 \%$ and $21 \%$, respectively, were obtained as Rhodococcus equi was cultured on hexadecane (insoluble in water) and glycerol (soluble in water).

The bacteria showed completely different surface properties when exposed to mixtures of hydrocarbons and the sophorolipid biosurfactant. The hydrophobicity of bacteria, which was already incubated on the weathered biodiesel, diesel and light crude oil, decreased as the mixtures of bacterial cells-hydrocarbons were exposed to an $80 \mathrm{mg} / \mathrm{L}$ of sophorolipid solution Figure 3. The highest bacterial cell modification was observed in the bacterial cell-diesel system. The hydrophobicity of diesel bacteria decreased from $+16 \%$ to $-20 \%$. The hydrophobicity of mixtures of the bacterial cell-biodiesel system decreased from $-50 \%$ to $-67 \%$ and the hydrophobicity of the bacterial cell-light crude oil system decreased from $+2 \%$ to $-11 \%$. All bacteria modified their cell surface properties to very hydrophilic states.

As reported by Baumgarten et al. [42] depending on the species of bacteria and the environmental conditions, the bacterial cell surface can be hydrophobic or hydrophilic. The bacteria with the high cell surface hydrophobicity are able to directly interact with the hydrophobic compounds such as hydrocarbons, while the bacteria with the low cell surface hydrophobicity can interact with the hydrophilic compounds or adhere to the hydrocarbons that are encapsulated in the micelles (because the outer layer of micelle is hydrophilic) [3,43-48]. The ability of microorganisms for cell surface modifications during incubation at different conditions [29,49-51] and the microbial cell modifications following the application of biosurfactants were previously reported $[40,49,50,52-56]$. The modification of the cell surface hydrophobicity is one of the strategies that microorganisms use to avoid contact with toxic compounds $[3,46,57]$ or to uptake food (e.g., hydrocarbons)
$[45,46]$. For example, some bacteria release vesicles (which is an intercellular structure and its outer membrane is a lipid bilayer) from the outer membrane [42], while others release lipopolysaccharide (LPS) to change the cell surface hydrophobicity [52].

Production of biosurfactant or emulsifying compounds is another way that bacteria change their cell surface structures. Beal and Betts [56] showed that the biosurfactant production in the biosurfactant producing bacteria (e.g., PG201, a rhamnolipid-producing bacteria) reduced the level of cell surface hydrophobicity (negative $\mathrm{CSH}$ ) as exposed to phenanthrene. Moreover, a study on the phenanthrene biodegradation by Pseudomonas sp. strain PP2 showed that the biosurfactant production by Pseudomonas during biodegradation and modifications of the cell surface hydrophobicity were the two adapted mechanisms by Pseudomonas for the phenanthrene uptake [41]. Similarly, Pseudomonas strains consumed hydrocarbons by the production of rhamnolipid biosurfactants, which accelerated the solubility of hydrophobic substrates. Production of the rhamnolipids made the Pseudomonas cell surface more hydrophilic and thus cells were able to uptake the encapsulated hydrocarbons in the micelles through contact with the outer layer of micelles, which is hydrophilic $[44,58]$.

One way to increase the hydrocarbon uptake by the microorganisms to add surfactants to the hydrocarbon contaminated systems (e.g., in the case of an oil spill). Although, some studies showed the insignificant effect of the addition of surfactant (e.g., rhamnolipid) on the cell structures [40], the changes in the cell surface hydrophobicity following the addition of biological surfactants was reported by investigators $[29,56]$. Increase in the biodegradation of hexadecane [56] and octadecane by Pseudomonas species [29] have highlighted the positive effects of external addition of biosurfactants on the hydrocarbons biodegradation. Similarly, the cell surface properties of gram negative bacteria such as $P$. fluorescens SM, A. hydrophila SM, $P$. alcaligenes $S M, A$. denitrificans $S M, P$. stutzeri $K S$ and $F$. oryzihabitans $P 1$ significantly increased in the presence of rhamnolipid [40]. A study conducted by Al-Tahhan et al. [52] showed that the increase in the cell surface hydrophobicity of Pseudomonas spp. in the presence of rhamnolipid was because the rhamnolipid biosurfactant changed the outer membrane of the bacteria so that the interaction between the rhamnolipid and the outer membrane of cells resulted in the loss of fatty acid content due to the release of lipopolysaccharide (LPS) [52].

Results of the hydrophobicity test showed that the bacterial communities in the diesel, biodiesel and light crude oil modified their cell surface structures based on the availability and the compositions of hydrocarbons. Moreover, the cell surface hydrophobicity was significantly influenced by the types of hydrocarbons and the presence of sophorolipid biosurfactant. For example, the initial hydrophilic nature of bacteria in the cell-biodiesel system (CSH of -50) suggests that the bacteria should be able to directly contact to the hydrophilic compounds of the biodiesel. On the other hand, the hydrophobic nature of the bacteria in the cell-diesel and the cell-light crude oil systems suggests that the direct contact with the hydrophobic compounds of diesel and light crude oil may be the primary way of hydrocarbon uptake by the bacteria.

In the system with the bacterial cells and only sophorolipid (80 $\mathrm{mg} / \mathrm{L}$ ), the exposure of bacteria to the sophorolipid biosurfactant significantly increased the bacterial cell surface hydrophobicity. This behavior seems normal, because the hydrophobic structure of the sophorolipid biosurfactant limited the availability of sophorolipid to the bacteria. The modification enabled the bacteria to interact directly 
Citation: Saborimanesh N, Mulligan CN (2015) Effect of Sophorolipid Biosurfactant on Oil Biodegradation by the Natural Oil-Degrading Bacteria on the Weathered Biodiesel, Diesel and Light Crude Oil. J Bioremed Biodeg 6: 314. doi:10.4172/2155-6199.1000314

with the hydrophobic sophorolipid biosurfactant.

The significant decreases in the hydrophobicities of the cellsophorolipid-diesel, biodiesel and light crude oil mixtures was because the sophorolipid biosurfactant increased the bioavailability of hydrocarbons (HCs) through the HC encapsulation in the micelles and the bacteria directly contacted with the hydrophilic micelles.

Several reasons can lead to the high levels of weathered diesel, biodiesel and light crude oil biodegradation in the natural and sophorolipid treatments. It seems that, the presence of natural oildegrading bacteria in the weathered biodiesel, diesel and light crude (Table 1) and the high capability of the dominant bacteria in the modification of cells surface structures Figure 3 can be the main reasons for the oil biodegradation. Moreover, the presence of readily consumable hydrocarbons slightly influenced the biodegradation, though the biodegradation due to the contact with the readily consumable hydrocarbons was limited. This is because the natural solubility of biodiesel (BD), light crude oil (L) and diesel (D) in the artificial seawater was insignificant (e.g., less than $5 \%$ for $\mathrm{BD}$ and less than $3 \%$ for $\mathrm{D}$ and $\mathrm{L}$ ). In addition, as the ability of bacteria in the production of $\mathrm{HC}$ degrading enzymes and biosurfactant compounds was previously reported by investigators [3,7,34-39] thus the biosurfactant production by the dominant bacteria in the weathered diesel, biodiesel and light crude oil was also considered as one of the possible reasons for the high oil biodegradation. Given the type of isolated bacteria in the biodiesel, diesel and light crude oil (Table 1), production of biosurfactant by such bacteria during the biodegradation process seemed possible. However, the surface tension measurements of the culture media (supernatant) of the bacteria recovered from the biodiesel, diesel and light crude oil showed an insignificant decrease in the surface tension during the bioremediation process. The surface tension measurements results did not support the significant biosurfactant production by the indigenous bacteria.

Investigations showed that chemical dispersants (e.g., Corexit 9500) and even biological dispersants (e.g., rhamnolipid) did not always lead to enhanced oil mineralization and biodegradation $[19,59]$. However, studies conducted by Koch et al. [60] suggested that the exposures of non-producing bacteria (e.g., a mutant strain of PG201) to pure rhamnolipid increased the uptakes of the hydrophobic compounds. The higher levels of biodegradation of diesel, biodiesel and light crude oil in the samples treated with sophorolipid biosurfactant suggested the high availability of hydrocarbons to the bacteria as the results of increase in the solubilization and dispersion of hydrocarbons by sophorolipid biosurfactant and the hydrocarbon encapsulation in the micelles (Figure 1), the ability of bacteria in the cell surface modifications based on the available HCs (Figure 3) and direct contact with the water-soluble hydrocarbons (e.g., biodiesel), respectively.

\section{Conclusions}

Several studies have assessed the role of oil-degrading bacteria isolated from seawater in the biodegradation of petroleum hydrocarbons $[7,22,61]$. Although those studies provided valuable information on the influence of such bacteria in the oil biodegradation in aqueous environments, they did not consider the importance of the microbial communities in the spilled oils in the oil biodegradation $[7,22,61]$. This study determined the presence of natural oil-degrading bacteria in the weathered diesel, biodiesel and light crude oil and the role of the bacteria in oil biodegradation in the presence and absence of the sophorolipid biosurfactant.
The findings from this study revealed the significant biodegradation of tested oils especially light crude oil in both natural and sophorolipid treatments. The biodegradation results and bacterial growth on the Bushnell-Hass media confirmed the presence of active oil-degrading bacteria in the tested oils. A comparison of the results obtained from the biodegradation study and the cell surface hydrophobicity tests suggested that the biodiesel, diesel and light crude oil biodegradation (in the natural treatment) by the bacteria was because the bacteria was able to uptake the oil droplets or the hydrophilic compounds by the direct interactions as the results of the cell surface modifications.. The mentioned mechanism for the natural (control) treatment could have also simultaneously occurred in the treatment with the sophorolipid biosurfactant. However, the hydrocarbon uptake by the bacteria in the sophorolipid treated samples was due to the encapsulation of biodiesel, diesel and light crude oil in the sophorolipid micellar aggregates.

This study confirmed that the indigenous oil-degrading bacteria in the weathered diesel, biodiesel and light crude oil had an important role in the oil biodegradation in the seawater and also the positive effect of external addition of the sophorolipid biosurfactant on the biodegradation.

\section{References}

1. McKew BA, Coulon F, Osborn AM, Timmis KN, McGenity TJ (2007) Determining the identity and roles of oil-metabolizing marine bacteria from the Thames Estuary, UK. Environmental Microbiology, 9: 165-176.

2. Liu JF, Mbadinga SM, Yang SZ, Gu JD, Mu BZ (2015) Chemical Structure, Property and Potential Applications of Biosurfactants Produced by Bacillus subtilis in Petroleum Recovery and Spill Mitigation. International Journal of Molecular Sciences, 16: 4814-4837.

3. Bouchez NM, Rakatozafy $H$, Marchal R, Leveau J, Vandecasteele J (1999) Diversity of bacterial strains degrading hexadecane in relation to the mode of substrate uptake. Journal of Applied Microbiology, 86: 421-428.

4. Fingas M (2011) Chapter 1: Introduction, Fingas, M. (Ed.), Oil Spill Science and Technology, USA, Gulf Professional Publishing, pp. 3-5.

5. Zhang Y, Miller RM (1992) Enhanced Octadecane Dispersion and Biodegradation by a Pseudomonas Rhamnolipid Surfactant (Biosurfactant). Applied and Environmental Microbiology, 58: 3276-3282.

6. Okafor N (2011) Chapter 7: Pollution by Petroleum in Oceans and Seas: Role of Microorganisms in Oil Degradation and Remediation, Environmental Microbiology of Aquatic and Waste Systems, 1 ed., Springer Netherlands, pp. 307 .

7. Das N, Chandran $P(2010)$ Microbial degradation of petroleum hydrocarbon contaminants: an overview. Biotechnology Research International, 2011, 13.

8. Leahy JG, Colwell RR (1990) Microbial degradation of hydrocarbons in the environment. Microbiological Reviews, 54: 305-315.

9. Ward OP (2010) Chapter 5: Microbial Biosurfactants and Biodegradation, Sen, R. (Ed.), Biosurfactants Springer New York, pp. 65-74.

10. Ron EZ, Rosenberg E (2002) Biosurfactants and oil bioremediation. Current Opinion in Biotechnology, 13: 249-252.

11. Tzintzun-Camacho O, Loera O, Ramírez-Saad HC, Gutiérrez-Rojas M (2012) Comparison of mechanisms of hexadecane uptake among pure and mixed cultures derived from a bacterial consortium. International Biodeterioration \& Biodegradation, 70: 1-7.

12. Bouchez-Naïtali M, Vandecasteele JP (2008) Biosurfactants, an help in the biodegradation of hexadecane? The case of Rhodococcus and Pseudomonas strains. World Journal of Microbiology and Biotechnology, 24: 1901-1907.

13. Sekelsky AM, Shreve GS (1999) Kinetic model of biosurfactant enhanced hexadecane biodegradation by Pseudomonas aeruginosa. Biotechnology and Bioengineering, 63: 401-409.

14. Klevens HB (1950) The Solubilization of Polycyclic Hydrocarbons. The Journa of Physical and Colloid Chemistry, 54: 283-298.

15. Clayton JR, Payne JR, Farlow JS (1993) Section 1: Introduction, Oil Spil 
Citation: Saborimanesh N, Mulligan CN (2015) Effect of Sophorolipid Biosurfactant on Oil Biodegradation by the Natural Oil-Degrading Bacteria on the Weathered Biodiesel, Diesel and Light Crude Oil. J Bioremed Biodeg 6: 314. doi:10.4172/2155-6199.1000314

Dispersants: Mechanisms of Action and Laboratory Tests, CRC Press, pp. 1-4.

16. Lessard RR, DeMarco G (2000) The Significance of Oil Spill Dispersants. Spill Science \& Technology Bulletin, 6: 59-68.

17. Rosen MJ (2004) Chapter 2: Adsorption of Surface-Active Agents at Interfaces: The Electrical Double Layer, Surfactants and Interfacial Phenomena, Third ed. John Wiley \& Sons, Inc., pp. 34-104.

18. Rosen MJ (2004) Chapter 3: Micelle Formation by Surfactants, Surfactants and Interfacial Phenomena, Third ed., John Wiley \& Sons, Inc., pp. 105-177.

19. Lindstrom JE, Braddock JF (2002) Biodegradation of petroleum hydrocarbons at low temperature in the presence of the dispersant Corexit 9500. Marine Pollution Bulletin, 44: 739-747.

20. Owsianiak M, Chrzanowski Ł, Szulc A, Staniewski J, Olszanowski A et al. (2009) Biodegradation of diesel/biodiesel blends by a consortium of hydrocarbon degraders: Effect of the type of blend and the addition of biosurfactants. Bioresource Technology, 100: 1497-1500.

21. Brakstad O, Lødeng A (2005) Microbial diversity during biodegradation of crude oil in seawater from the North Sea. Microbial Ecology, 49: 94-103.

22. Sheppard PJ, Keryn LS, Krishna KK, Sayali SP, Andrew SB (2012) The Importance of Weathered Crude Oil as a Source of Hydrocarbonoclastic Microorganisms in Contaminated Seawater. Microbial Biotechnology, 22: 11851192.

23. Wang Z, Fingas M, Blenkinsopp S, Sergy G, Landriault M et al. (1998) Comparison of oil composition changes due to biodegradation and physical weathering in different oils. Journal of Chromatography A, 809: 89-107.

24. USEPA (2011) Appendix C to Part 300 - Swirling Flask Dispersant Effectiveness Test, Revised Standard Dispersant Toxicity Test, and Bioremediation Agent Effectiveness Test. Environmental Protection Agency 28: 225-247.

25. Pepper IL, Gerba CP (2015) Chapter 10 - Cultural Methods, Pepper, I.L., Gerba, C.P., and Gentry, T.J. (Eds.), Environmental Microbiology Third ed. San Diego, Academic Press, pp. 195-212.

26. Cole JR, Wang Q, Cardenas E, Fish J, Chai B et al. (2009) The Ribosomal Database Project: improved alignments and new tools for rRNA analysis. Nucleic Acids Research, 37: D141-D145.

27. Claesson MJ, O'Sullivan O, Wang Q, Nikkilä J, Marchesi JR et al. (2009) Comparative analysis of pyrosequencing and a phylogenetic microarray for exploring microbial community structures in the human distal intestine. PLOS ONE, 4: e6669.

28. Rosenberg M, Gutnick D, Rosenberg E (1980) Adherence of bacteria to hydrocarbons: a simple method for measuring cell-surface hydrophobicity. FEMS Microbiology Letters, 9: 29-33.

29. Zhang Y, Miller RM (1994) Effect of a Pseudomonas Rhamnolipid Biosurfactan in Cell Hydrophobicity and Biodegradation of Octadecane. Applied and Environmental Microbiology, 60: 2101-2106.

30. Head IM, Jones DM, Röling WF (2006) Marine microorganisms make a meal of oil. Nature Reviews Microbiology, 4: 173-182.

31. Yakimov MM, Timmis KN, Golyshin PN (2007) Obligate oil-degrading marine bacteria. Current Opinion in Biotechnology, 18: 257-266.

32. Ron EZ, Rosenberg E (2001) Natural roles of biosurfactants. Environmental Microbiology, 3: 229-236.

33. Bødtker G, Hvidsten IV, Barth T, Torsvik T (2009) Hydrocarbon degradation by Dietzia sp. A14101 isolated from an oil reservoir model column. Antonie Van Leeuwenhoek, 96: 459-469.

34. Ganesh A, Lin J (2009) Diesel degradation and biosurfactant production by Gram-positive isolates. African Journal of Biotechnology, 8: 5847-5854.

35. Bodour AA, Drees KP, Maier RM (2003) Distribution of biosurfactant-producing bacteria in undisturbed and contaminated arid southwestern soils. Applied and Environmental Microbiology, 69: 3280-3287.

36. Menezes Bento F, de Oliveira Camargo FA, Okeke BC, Frankenberger Jr, WT (2005) Diversity of biosurfactant producing microorganisms isolated from soils contaminated with diesel oil. Microbiological Research, 160: 249-255.

37. Płaza G, Łukasik K, Wypych J, Nałęcz-Jawecki G, Berry C et al. (2008) Biodegradation of crude oil and distillation products by biosurfactant-producing bacteria. Polish Journal of Environmental Studies, 17: 87-94.
38. Kumari B, Singh S, Singh, D (2012) Characterization of two biosurfactant producing strains in crude oil degradation. Process Biochemistry, 47: 24632471.

39. Banat IM, Franzetti A, Gandolfi I, Bestetti G, Martinotti MG (2010) Microbial biosurfactants production, applications and future potential. Applied Microbiology and Biotechnology, 87: 427-444.

40. Kaczorek E (2012) Effect of External Addition of Rhamnolipids Biosurfactant on the Modification of Gram Positive and Gram Negative Bacteria Cell Surfaces during Biodegradation of Hydrocarbon Fuel Contamination. Polish Journal of Environmental Studies, 21: 901-909.

41. Prabhu Y, Phale P (2003) Biodegradation of phenanthrene by Pseudomonas sp. strain PP2: novel metabolic pathway, role of biosurfactant and cell surface hydrophobicity in hydrocarbon assimilation. Applied Microbiology and Biotechnology, 61: 342-351.

42. Baumgarten T, Sperling S, Seifert J, von Bergen M, Steiniger F et al. (2012) Membrane vesicle formation as a multiple-stress response mechanism enhances Pseudomonas putida DOT-T1E cell surface hydrophobicity and biofilm formation. Applied and Environmental Microbiology, 78: 6217-6224

43. Van Hamme JD, Singh A, Ward OP (2003) Recent advances in petroleum microbiology. Microbiology and Molecular Biology Reviews, 67: 503-549.

44. Franzetti A, Tamburini E, Banat IM (2010) Chapter 9: Applications of Biological Surface Active Compounds in Remediation Technologies, Sen, R. (Ed.), Biosurfactants, Springer New York, pp. 121-134.

45. Kaczorek E, Chrzanowski L, Pijanowska A, Olszanowski A (2008) Yeast and bacteria cell hydrophobicity and hydrocarbon biodegradation in the presence of natural surfactants: rhamnolipides and saponins. Bioresource Technology, 99: 4285-4291.

46. Krasowska A, Sigler K (2014) How microorganisms use hydrophobicity and what does this mean for human needs? Frontiers in Cellular and Infection Microbiology, 4: 7 .

47. Kochkodan V, Tsarenko S, Potapchenko N, Kosinova V, Goncharuk V (2008) Adhesion of microorganisms to polymer membranes: a photobactericidal effect of surface treatment with TiO2. Desalination, 220: 380-385.

48. Giaouris E, Chapot-Chartier MP, Briandet R (2009) Surface physicochemical analysis of natural Lactococcus lactis strains reveals the existence of hydrophobic and low charged strains with altered adhesive properties. International Journal of Food Microbiology, 131: 2-9.

49. Zhong $\mathrm{H}$, ming Zeng G, Yuan XZ, yan Fu H, Huang GH et al. (2007) Adsorption of dirhamnolipid on four microorganisms and the effect on cell surface hydrophobicity. Applied Microbiology and Biotechnology, 77: 447-455.

50. Kaczorek E, Urbanowicz M, Olszanowski A (2010) The influence of surfactants on cell surface properties of Aeromonas hydrophila during diesel oil biodegradation. Colloids and Surfaces B: Biointerfaces, 81: 363-368.

51. Rosenberg M, Kjelleberg S (1986) Hydrophobic interactions: role in bacterial adhesion, Advances in Microbial Ecology, Springer, pp. 353-393.

52. Al-Tahhan RA, Sandrin TR, Bodour AA, Maier RM (2000) Rhamnolipid-Induced Removal of Lipopolysaccharide from Pseudomonas aeruginosa: Effect on Cell Surface Properties and Interaction with Hydrophobic Substrates. Applied and Environmental Microbiology, 66: 3262-3268.

53. Noordman WH, Janssen DB (2002) Rhamnolipid Stimulates Uptake of Hydrophobic Compounds by Pseudomonas aeruginosa. Applied and Environmental Microbiology, 68: 4502-4508.

54. Kaczorek E, Jesionowski T, Giec A, Olszanowski A (2012) Cell surface properties of Pseudomonas stutzeri in the process of diesel oil biodegradation Biotechnology Letters, 34: 857-862.

55. Zhang Y, Miller RM (1995) Effect of rhamnolipid (biosurfactant) structure on solubilization and biodegradation of $n$-alkanes. Applied and Environmental Microbiology, 61: 2247-2251.

56. Beal R, Betts W (2000) Role of rhamnolipid biosurfactants in the uptake and mineralization of hexadecane in Pseudomonas aeruginosa. Journal of Applied Microbiology, 89: 158-168.

57. Torres S, Pandey A, Castro GR (2011) Organic solvent adaptation of Gram positive bacteria: applications and biotechnological potentials. Biotechnology Advances, 29: 442-452.

58. Van Hamme JD, Ward OP (2001) Physical and metabolic interactions of 
Citation: Saborimanesh N, Mulligan CN (2015) Effect of Sophorolipid Biosurfactant on Oil Biodegradation by the Natural Oil-Degrading Bacteria on the Weathered Biodiesel, Diesel and Light Crude Oil. J Bioremed Biodeg 6: 314. doi:10.4172/2155-6199.1000314

Pseudomonas sp. strain JA5-B45 and Rhodococcus sp. strain F9-D79 during growth on crude oil and effect of a chemical surfactant on them. Applied and Environmental Microbiology, 67: 4874-4879.

59. Bruheim P, Bredholt $H$, Eimhjellen K (1997) Bacterial degradation of emulsified crude oil and the effect of various surfactants. Canadian Journal of Microbiology, 43: $17-22$.
60. Koch AK, Käppeli O, Fiechter A, Reiser J (1991) Hydrocarbon assimilation and biosurfactant production in Pseudomonas aeruginosa mutants. Journal of Bacteriology, 173: 4212-4219.

61. Harayama S, Kasai Y, Hara A (2004) Microbial communities in oil-contaminated seawater. Current Opinion in Biotechnology, 15: 205-214.
Citation: Saborimanesh N, Mulligan CN (2015) Effect of Sophorolipid Biosurfactant on Oil Biodegradation by the Natural Oil-Degrading Bacteria on the Weathered Biodiesel, Diesel and Light Crude Oil. J Bioremed Biodeg 6: 314. doi:10.4172/2155-6199.1000314
OMICS International: Publication Benefits \& Features

\section{Unique features:}

Increased global visibility of articles through worldwide distribution and indexing

Showcasing recent research output in a timely and updated manner

Special issues on the current trends of scientific research

\section{Special features:}

700 Open Access Journals

50,000 Editorial team

Rapid review process

Quality and quick editorial, review and publication processing

Indexing at PubMed (partial), Scopus, EBSCO, Index Copernicus, Google Scholar etc.

Sharing Option: Social Networking Enabled

Authors, Reviewers and Editors rewarded with online Scientific Credits

Better discount for your subsequent articles

Submit your manuscript at: http://www.omicsonline.org/submission 